\title{
Effect of biotic and abiotic factors on the biochemical composition of wild eggs and larvae of several fish species
}

\author{
C. Guisande*, I. Riveiro, A. Solá**, L. Valdés*** \\ Facultad de Ciencias del Mar, Universidad de Vigo, Aptdo. 874, E-36200 Vigo, Spain
}

\begin{abstract}
The aim of this study is to establish possible associations between temperature, salinity and egg and larval abundance, and the biochemical composition of wild fertilised eggs and larvae of marine fish species. Eggs and larvae of the most abundant species at each station at the time of sampling were collected during 2 surveys carried out from 25 March to 14 April 1995 (MPH-95) for collecting eggs and from 30 May to 16 June (SEFOS-95) for collecting larvae. Both surveys were carried out on the N-NW coast of the Iberian Peninsula. Egg size, egg abundance, egg stage, temperature and salinity explained a small variance in the high variation observed within and between stations in protein, carbohydrate and lipid content of the eggs in both Trachurus trachurus and Scomber scombrus. Conversely, protein, carbohydrate and lipid content of larvae in Sardina pilchardus, Engraulis encrasicolus and $T$ trachurus seemed to vary according to either larval body length, temperature, salinity and/or larval abundance. Protein, carbohydrate and lipid content increased as larval body length increased for the 3 species. However, a percentage of lipid and protein in the larvae of the 3 species varied according to prevailing buoyancy conditions. An increment of larval lipid percentage and a reduction of larval protein percentage was observed as temperature increased and salinity decreased, the opposite case causing an increase in protein percentage and a decrease in lipid percentage of the larvae. This trade-off between protein and lipid production is interpreted as a mechanism to achieve optimal larval buoyancy.
\end{abstract}

KEY WORDS: Protein · Carbohydrate - Lipid - Egg · Larva - Temperature - Salinity - Sardina pulchardus Trachurus trachurus $\cdot$ Scomber scombrus - Engraulis encrasicolus

\section{INTRODUCTION}

Most of the knowledge on energy reserves and energy metabolism in developing fish eggs and larvae has been primarily based on eggs that have been naturally or artificially fertilised in culture tanks (Watanabe 1982, Vetter et al. 1983, Fyhn \& Serigstad 1987, Fyhn 1989, Miranda et al. 1990, Finn et al. 1991, Srivastava \& Brown 1991, Tamaru et al. 1992). Little information exists in the literature on bioenergetic studies

\footnotetext{
•E-mail: castor@uvigo.es

Present addresses:

- Instituto Español de Oceanografía, Avda. de Brasil, 31 , E-28020 Madrid, Spain

-.Centro Oceanográfico de Santander, Instituto Español de Oceanografía, Aptdo. 240, E-39080 Santander, Spain
}

on fertilised eggs and larvae directly collected from the natural environment where the quality of eggs produced by females can be affected by biotic factors such as egg and larval abundance and abiotic factors such as temperature and salinity.

Egg abundance could affect egg biochemical composition from the viewpoint of an optimum balance between offspring number and size (Buckley et al. 1991 b). Larval abundance could also affect larval biochemical composition due to a possible food depletion caused by a high intraspecific competition.

Temperature and salinity affect egg and larval buoyancy. Egg buoyancy has been shown as an important factor affecting success of fish spawning, mainly for 2 reasons. Firstly, eggs must stay buoyant in the upper water to avoid low oxygen conditions of deep layers (Nissling \& Westin 1991) and, secondly, eggs must 
reach an appropriate water depth for larval feeding by the time of hatching (Page et al. 1989). As there is a spatial and temporal variability in both temperature and salinity, hence in egg buoyancy (Coombs et al. 1985), any change in egg density directed toward achieving optimal buoyancy could benefit the recruitment processes. Egg buoyancy can vary according to egg water content (Craik \& Harvey 1987) and chorion thickness (Kjesbu et al. 1992). Differences in egg density can also occur as a result of changes in egg quality, with eggs' low specific weight relative to sea water when egg quality is poorer (Kjesbu et al. 1992). On the other hand, many studies have also pointed out the importance of water density for larval spatial distribution. Lee et al. (1995) showed that surface water temperature and salinity were important factors associated with the formation of larval anchovy fishing grounds. Anderson \& DeYoung (1995) demonstrated that vertical distribution of cod eggs and larvae was sensitive to changes in water temperature and salinity, showing a progression from deeper to shallower depths as cod eggs develop through to larvae. Page et al. (1989) pointed out the importance for larval survival of staying in the upper more productive layers. Therefore, changes in either protein, carbohydrate or lipid percentages of the eggs and larvae could be observed as a mechanism to achieve optimal egg and larval buoyancy.

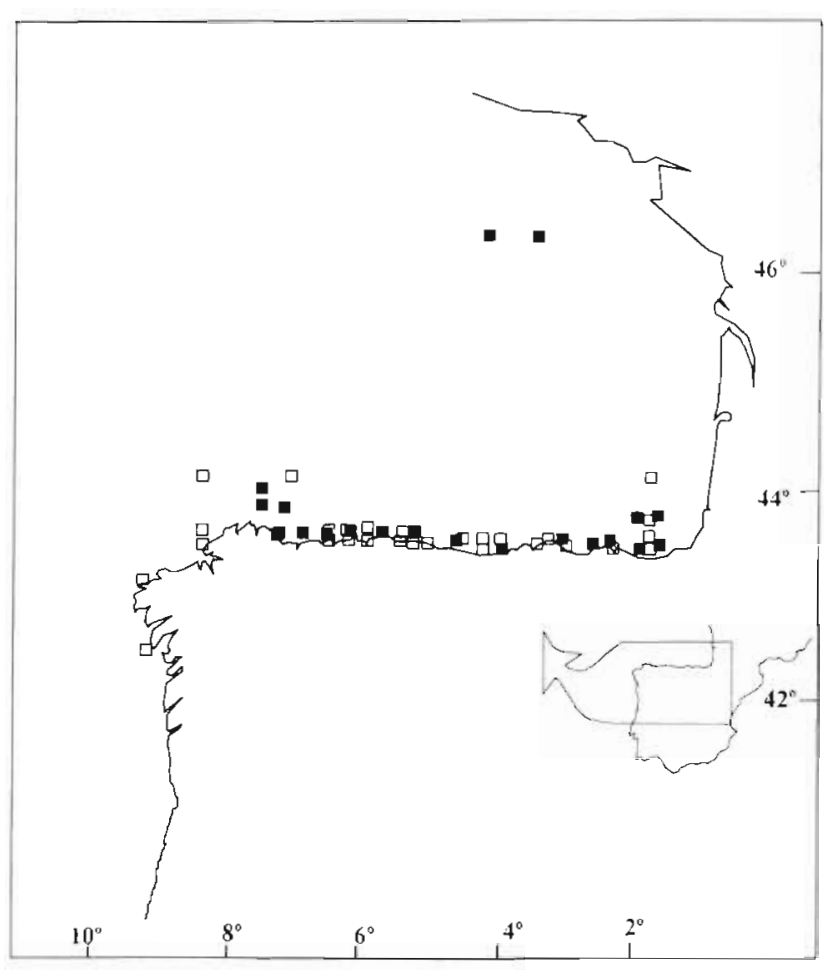

Fig. 1. Map of study area, showing location of sampling stations during MPH-95 (ם) and SEFOS-95 (-) cruises
The aims of this study were to determine changes in protein, carbohydrate and lipid composition during the development of eggs and larvae collected from natural fish populations and to discover whether protein, carbohydrate and lipid content of eggs and larvae could be associated to changes in temperature, salinity and/ or egg and larval abundance.

\section{METHODS}

Wild fertilised eggs and larvae of the most abundant species at each station at the time of sampling were collected during 2 surveys carried out from 25 March to 14 April 1995 (MPH-95) for collecting eggs and from 30 May to 16 June (SEFOS-95) for collecting larvae on the RV 'Cornide de Saavedra'. Fig. 1 shows the location of sampling stations for both surveys. These sampling stations and periods were chosen because previous studies have shown that the main spawning of the most abundant species in the Cantabrian Sea occurs in these areas: from April to May for Scomber scombrus, from May to June for Trachurus trachurus and, although the spawning period of Sardina pilchardus extends almost throughout the whole year, the main and consistent peak occurs from April to May (Solá et al. 1990).

As this survey formed a part of an EEC project, we used integrated tows following the ICES basis of the Mackerel/Horse mackerel egg production workshop (Anonymous 1994) and, hence, information on the depth distribution of eggs and larvae was not obtained. Oblique tows were performed using a $50 \mathrm{~cm}$ diameter bongo net fitted with $200 \mu \mathrm{m}$ mesh. Eggs and live larvae were immediately removed from the plankton samples using pipettes and, after examination under a binocular microscope equipped with an ocular micrometer, egg diameter or larval body length was measured and embryonic developmental stages were determined according to the morphological criteria of Lockwood \& Nichols (1977) for Scomber scombrus and Pipe \& Walker (1987) for Trachurus trachurus. Eggs or larvae were then transferred to individual $1.5 \mathrm{ml}$ ultracentrifuge plastic tubes where each egg was homogenised in either $300 \mu \mathrm{l}$ (to analyse protein and lipid) or $500 \mu \mathrm{l}$ (to analyse carbohydrate and lipid) and each larva in $675 \mu \mathrm{l}$ (to analyse protein, carbohydrate and lipid) of distilled water using a pipette tip adapted to fit the shape of the vial. Therefore, for each larva protein, carbohydrate and lipid content were analysed, whereas for each egg either protein and lipid or carbohydrate and lipid were analysed. These samples were immediately frozen on board for further laboratory analysis of egg and larval biochemical composition 
Protein, carbohydrate and lipid percentage were calculated considering total organic content as the combined total protein, carbohydrate and lipid content of eggs and larvae.

Egg and larval biochemical composition analysis. For each individual egg or larva homogenate, $200 \mu \mathrm{l}$ was used for protein analysis, $400 \mu$ for carbohydrate analysis and $75 \mu$ for lipid analysis. The method described by Lowry et al. (1951) and modified by Markwell et al. (1978) was used to analyse the protein content of the eggs. To sample volumes of $200 \mu \mathrm{l}, 50 \mu \mathrm{l} \mathrm{NaOH}(0.5 \mathrm{~N})$ (prepared just before the test) and $750 \mu$ l of solution $\mathrm{C}$ were added. Solution $C$ was prepared shortly before the beginning of the analysis and was composed of solutions $\mathrm{A}$ and $\mathrm{B}$ in the proportions of $100 \mathrm{~A}: 1 \mathrm{~B}$. These solutions were as follows: solution $\mathrm{A}_{1} \mathrm{Na}_{2} \mathrm{CO}_{3}(2 \%), \mathrm{NaOH}(0.4 \%)$, $\mathrm{NaK}(\mathrm{COO})_{2}(\mathrm{CHOH})_{2} 4 \mathrm{H}_{2} \mathrm{O}(0.16 \%)$, SDS $(1 \%)$; solution $\mathrm{B}, \mathrm{CuSO}_{4} 5 \mathrm{H}_{2} \mathrm{O}(4 \%)$. The samples were shaken and maintained at $30^{\circ} \mathrm{C}$ for $15 \mathrm{~min}$. Then $75 \mu \mathrm{l}$ of diluted 1:1 Folin-Cioccalteus was added to each sample. Subsequently, the samples were incubated for $30 \mathrm{~min}$ at the same temperature. Absorbance was read at $660 \mathrm{~nm}$ and compared with bovine serum albumin (BSA) standard.

Egg and larval carbohydrate content was measured by the phenol-sulphuric acid method of Dubois et al. (1956). To sample volumes of $400 \mu \mathrm{l}, 10 \mu \mathrm{l}$ of $81 \%$ phenol was added and, after gently shaking, $1 \mathrm{ml}$ of concentrated sulphuric acid was added. The samples were shaken again and maintained at room temperature for $30 \mathrm{~min}$. Finally, the absorbance was read at $485 \mathrm{~nm}$. A standard curve was established by using reagentgrade glucose.

Egg and larval lipid content was determined using the sulfophosphovanillin method of Zöllner \& Kirsch (1962). $50 \mu$ of absolute ethanol was added to sample volumes of $75 \mu \mathrm{l}$ immediately after the sample was shaken and maintained at $4^{\circ} \mathrm{C}$ for at least $2 \mathrm{~h}$. Then $375 \mu$ l of concentrated sulphuric acid was added and later, after samples had been homogenised by shaking, the tubes were maintained at $100^{\circ} \mathrm{C}$ for $15 \mathrm{~min}$. After hydrolysis, when the tubes had cooled down, $2 \mathrm{ml}$ of vanillin reagent was added. Absorbance was read at $530 \mathrm{~nm}$, with cholesterol as standard, after tubes had been shaken and incubated at $30^{\circ} \mathrm{C}$ for $30 \mathrm{~min}$ Vanillin reagent was prepared by mixing $1.976 \mathrm{~g}$ of vanillin with $800 \mathrm{ml}$ of $85 \% \mathrm{H}_{3} \mathrm{PO}_{4}$ and distilled water to $1000 \mathrm{ml}$.

Hydrographic sampling. Hydrographic sampling was carried out by CTD cast. The CTD used was a SeaBird 25. Water samples were taken from the surface, 500 and $1000 \mathrm{~m}$ depth for CTD calibrations. Salinity analysis of the water samples was made on board using a 2100 MINISAL salinometer calibrated with standard water. Since we used integrated tows, there was no information on egg and larval depth distribution and, hence, temperature and salinity at each station were calculated as the mean of the values taken every $5 \mathrm{~m}$ as far as the bongo tow depth. However, it is important to mention that temperature and salinity at the depth at which eggs or larvae are distributed could be different from these mean values.

\section{RESULTS}

Table 1 shows tow characteristics and mean temperature and salinity of the whole water column for all the stations sampled in both surveys.

A high variation between and within stations in protein, carbohydrate and lipid content of eggs was observed for Scomber scombrus and Trachurus trachurus (Table 2). Stepwise regressions show that neither egg size, egg stage, temperature, salinity nor egg abundance explained a high proportion of this variation found in protein, carbohydrate and lipid content of the eggs for both species (Table 3 ).

In contrast, a high proportion of the variation observed in larval protein, carbohydrate and lipid contents for Sardina pilchardus, Trachurus trachurus and Engraulis encrasicolus between and within stations (Table 4) was explained either by larval size, temperature, salinity and/or larval abundance (Table 5). An increment in total protein, carbohydrate and lipid content of larvae was obtained as larval size increased for the 3 species (Table 5). However, protein and lipid contents of larvae were also affected by the temperature and salinity of the water. At higher temperature and lower salinity, hence lower buoyancy for the larvae, a reduction in larval protein percentage and an increment in larval lipid percent were observed, the opposite being the case as temperature decreased and salinity increased (Table 5, Fig. 2). In the case of $T$. trachurus and $E$. encrasicolus the relationships between protein and lipid percentage with temperature were not as significant as for S. pilchardus (Fig. 2). This is probably due to the low number of data and the small temperature range.

These changes in the biochemical composition of the larvae as temperature varied were not associated to changes in larval organic content. Fig. 3 shows that, considering the 4 species, there was a significant relationship between total organic content (combined total protein, carbohydrate and lipid content of eggs and larvae) and either egg or larval size. Therefore, for the same larval size, there is a trade-off between protein and lipid production according to a larva's specific weight relative to sea water, so that the organic content remains the same. 
Table 1. Summary of tow characteristics and mean \pm SD temperature and salinity of the whole water column at sampling stations located on the N-NW coast of the Iberian Peninsula from 25 March to 14 April 1995 (MPH-95) and from 30 May to 16 June 1995 (SEFOS-95)

\begin{tabular}{|c|c|c|c|c|c|c|}
\hline Stn & Lat. N & Long. W & Depth & $\begin{array}{l}\text { Bongo tow } \\
\text { depth }(\mathrm{m})\end{array}$ & $\begin{array}{l}\text { Temperature } \\
\left({ }^{\circ} \mathrm{C}\right)\end{array}$ & $\begin{array}{c}\text { Salinity } \\
(\% \circ)\end{array}$ \\
\hline \multicolumn{7}{|c|}{ MPH-95 } \\
\hline 31 & $42.4509^{\circ}$ & $9.2007^{\circ}$ & 125 & 121 & $12.51 \pm 0.46$ & $35.29 \pm 2.36$ \\
\hline 38 & $43.1506^{\circ}$ & $9.1465^{\circ}$ & 127 & 103 & $12.50 \pm 0.68$ & $35.32 \pm 2.27$ \\
\hline 45 & $43.3736^{\circ}$ & $8.3038^{\circ}$ & 162 & 133 & $12.53 \pm 0.37$ & $35.22 \pm 3.06$ \\
\hline 46 & $43.5239^{\circ}$ & $8.3008^{\circ}$ & 266 & 179 & $12.62 \pm 0.09$ & $35.46 \pm 0.83$ \\
\hline 47 & $44.0752^{\circ}$ & $8.3017^{\circ}$ & 360 & 173 & $12.30 \pm 0.41$ & $35.45 \pm 1.38$ \\
\hline 54 & $44.0774^{\circ}$ & $7.0983^{\circ}$ & 995 & 197 & $12.40 \pm 0.29$ & $34.81 \pm 0.73$ \\
\hline 55 & $43.5255^{\circ}$ & $7.2973^{\circ}$ & 145 & 113 & $12.51 \pm 0.32$ & $34.91 \pm 0.35$ \\
\hline 56 & $43.3757^{\circ}$ & $6.4993^{\circ}$ & 92 & 81 & $12.42 \pm 0.27$ & $34.99 \pm 3.77$ \\
\hline 57 & $43.5298^{\circ}$ & $6.5027^{\circ}$ & 125 & 84 & $12.09 \pm 0.22$ & $34.39 \pm 3.34$ \\
\hline 63 & $43.5269^{\circ}$ & $6.3032^{\circ}$ & 262 & 194 & $12.30 \pm 0.21$ & $35.27 \pm 0.66$ \\
\hline 64 & $43.3751^{\circ}$ & $6.2988^{\circ}$ & 100 & 79 & $12.18 \pm 0.12$ & $35.22 \pm 2.14$ \\
\hline 65 & $43.3760^{\circ}$ & $6.0999^{\circ}$ & 87 & 71 & $12.38 \pm 0.22$ & $35.37 \pm 1.85$ \\
\hline 66 & $43.5289^{\circ}$ & $6.1001^{\circ}$ & 674 & 192 & $12.38 \pm 0.26$ & $35.37 \pm 2.20$ \\
\hline 69 & $43.5261^{\circ}$ & $5.5011^{\circ}$ & 218 & 178 & $12.39 \pm 0.39$ & $35.35 \pm 1.87$ \\
\hline 70 & $43.4269^{\circ}$ & $5.5015^{\circ}$ & 116 & 105 & $12.34 \pm 0.35$ & $35.01 \pm 1.27$ \\
\hline 71 & $43.3748^{\circ}$ & $5.2988^{\circ}$ & 92 & 87 & $12.26 \pm 0.30$ & $35.29 \pm 1.79$ \\
\hline 72 & $43.5275^{\circ}$ & $5.3012^{\circ}$ & 245 & 215 & $12.33 \pm 0.37$ & $35.12 \pm 0.60$ \\
\hline 79 & $43.3746^{\circ}$ & $5.1001^{\circ}$ & 138 & 118 & $12.31 \pm 0.26$ & $35.30 \pm 3.46$ \\
\hline 80 & $43.3757^{\circ}$ & $4.4989^{\circ}$ & 153 & 120 & $12.62 \pm 0.36$ & $35.28 \pm 1.64$ \\
\hline 86 & $43.3789^{\circ}$ & $4.3001^{\circ}$ & 198 & 180 & $12.47 \pm 0.37$ & $35.22 \pm 2.51$ \\
\hline 87 & $43.2750^{\circ}$ & $4.3003^{\circ}$ & 125 & 105 & $12.31 \pm 0.40$ & $34.99 \pm 0.95$ \\
\hline 88 & $43.3781^{\circ}$ & $4.1004^{\circ}$ & 957 & 231 & $12.42 \pm 0.42$ & $35.24 \pm 3.48$ \\
\hline 94 & $43.3770^{\circ}$ & $3.4937^{\circ}$ & 176 & 176 & $12.52 \pm 0.43$ & $35.32 \pm 1.57$ \\
\hline 95 & $43.3768^{\circ}$ & $3.2995^{\circ}$ & 1089 & 221 & $12.37 \pm 0.56$ & $35.34 \pm 1.41$ \\
\hline 97 & $43.2754^{\circ}$ & $3.0999^{\circ}$ & 77 & 68 & $12.64 \pm 0.61$ & $34.94 \pm 2.64$ \\
\hline 101 & $43.2749^{\circ}$ & $2.2990^{\circ}$ & 96 & 92 & $12.72 \pm 0.24$ & $34.58 \pm 3.15$ \\
\hline 104 & $43.2738^{\circ}$ & $1.4518^{\circ}$ & 145 & 74 & $12.66 \pm 0.34$ & $35.59 \pm 2.91$ \\
\hline 105 & $43.3735^{\circ}$ & $1.4515^{\circ}$ & 416 & 251 & $12.31 \pm 0.50$ & $35.15 \pm 1.91$ \\
\hline 106 & $43.5234^{\circ}$ & $1.4500^{\circ}$ & 116 & 86 & $12.59 \pm 0.36$ & $34.68 \pm 2.96$ \\
\hline 107 & $44.1490^{\circ}$ & $1.4493^{\circ}$ & 116 & 103 & $12.45 \pm 0.51$ & $34.05 \pm 4.06$ \\
\hline \multicolumn{7}{|c|}{ SEFOS-95 } \\
\hline 2 & $43.5250^{\circ}$ & $7.4596^{\circ}$ & 133 & 125 & $13.33 \pm 1.09$ & $35.52 \pm 0.11$ \\
\hline 3 & $44.0736^{\circ}$ & $7.4532^{\circ}$ & 988 & 250 & $12.73 \pm 0.99$ & $35.56 \pm 0.06$ \\
\hline 9 & $43.5234^{\circ}$ & $7.1518^{\circ}$ & 154 & 120 & $13.34 \pm 1.27$ & $35.26 \pm 1.54$ \\
\hline 10 & $43.3743^{\circ}$ & $7.1512^{\circ}$ & 46 & 38 & $15.07 \pm 0.33$ & $35.55 \pm 5.54$ \\
\hline 11 & $43.3760^{\circ}$ & $6.4511^{\circ}$ & 90 & 72 & $14.41 \pm 0.79$ & $35.48 \pm 0.05$ \\
\hline 12 & $43.5219^{\circ}$ & $6.4532^{\circ}$ & 120 & 100 & $13.24 \pm 1.53$ & $35.50 \pm 0.11$ \\
\hline 20 & $43.3757^{\circ}$ & $6.1501^{\circ}$ & 77 & 57 & $13.66 \pm 1.60$ & $35.53 \pm 0.10$ \\
\hline 21 & $43.3766^{\circ}$ & $5.4360^{\circ}$ & 44 & 32 & $15.24 \pm 1.29$ & $35.35 \pm 0.13$ \\
\hline 30 & $43.3737^{\circ}$ & $5.1505^{\circ}$ & 135 & 115 & $13.10 \pm 1.48$ & $35.26 \pm 1.20$ \\
\hline 31 & $43.3892^{\circ}$ & $4.4490^{\circ}$ & 89 & 85 & $13.74 \pm 1.79$ & $35.38 \pm 0.22$ \\
\hline 40 & $43.2725^{\circ}$ & $4.1519^{\circ}$ & 89 & 79 & $13.81 \pm 1.71$ & $35.30 \pm 0.28$ \\
\hline 46 & $43.3770^{\circ}$ & $3.1492^{\circ}$ & 530 & 190 & $12.73 \pm 1.20$ & $35.56 \pm 0.70$ \\
\hline 55 & $43.3004^{\circ}$ & $2.4522^{\circ}$ & 110 & 88 & $13.46 \pm 1.91$ & $35.08 \pm 0.63$ \\
\hline 56 & $43.5251^{\circ}$ & $2.1508^{\circ}$ & 670 & 217 & $13.06 \pm 1.77$ & $35.31 \pm 0.47$ \\
\hline 58 & $43.2261^{\circ}$ & $2.1499^{\circ}$ & 101 & 95 & $13.19 \pm 1.52$ & $35.11 \pm 0.67$ \\
\hline 60 & $43.3849^{\circ}$ & $1.4410^{\circ}$ & 130 & 116 & $12.66 \pm 1.39$ & $35.35 \pm 0.46$ \\
\hline 61 & $43.5246^{\circ}$ & $1.4508^{\circ}$ & 120 & 106 & $13.73 \pm 1.71$ & $35.07 \pm 0.50$ \\
\hline 108 & $46.3731^{\circ}$ & $3.4517^{\circ}$ & 127 & 89 & $13.20 \pm 1.99$ & $35.17 \pm 0.33$ \\
\hline 109 & $46.3747^{\circ}$ & $4.1508^{\circ}$ & 144 & 136 & $13.04 \pm 1.54$ & $35.39 \pm 0.16$ \\
\hline
\end{tabular}




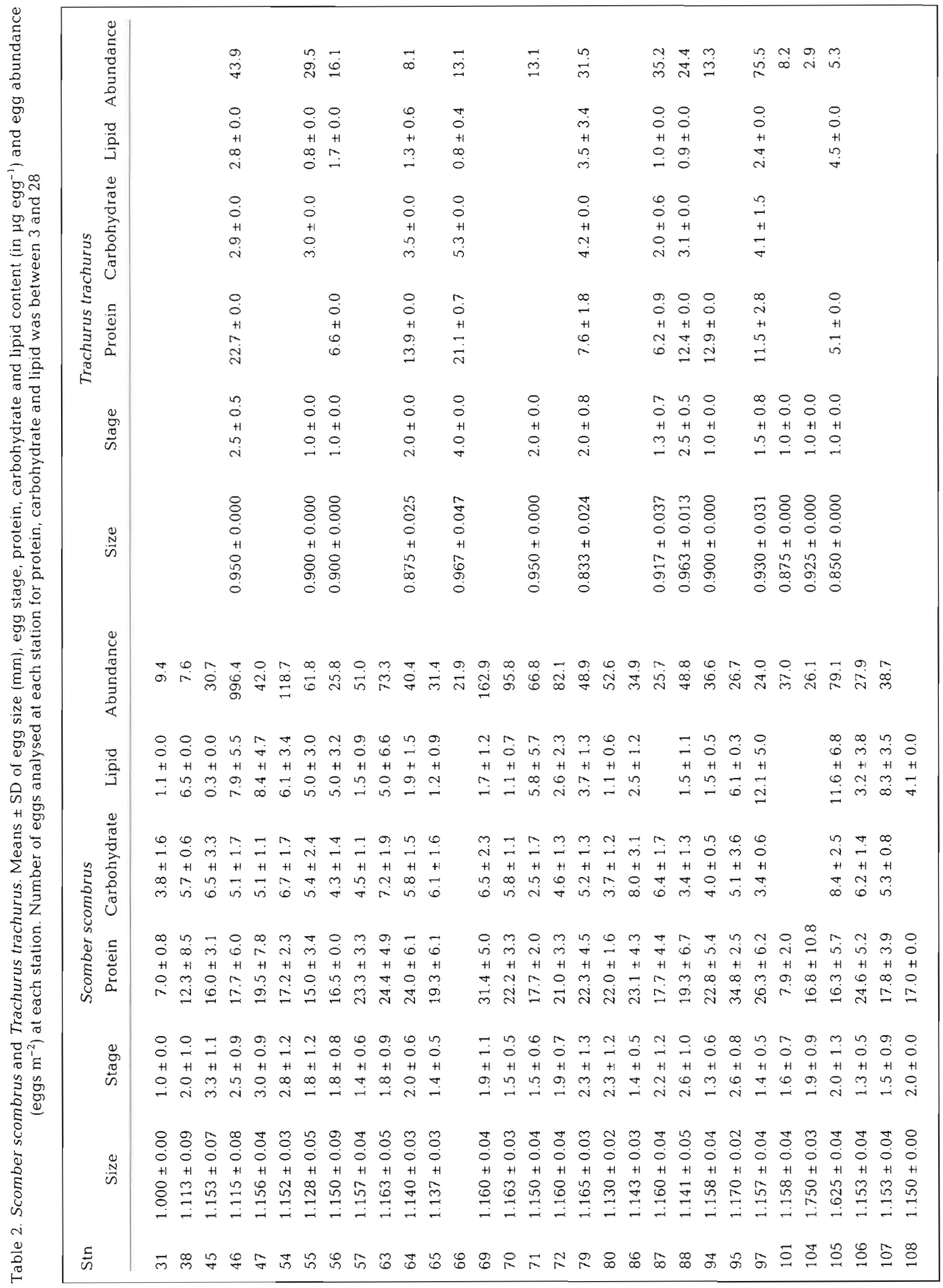


Table 3. Scomber scombrus and Trachurus trachurus. Stepwise linear regressions between total protein, carbohydrate and lipid

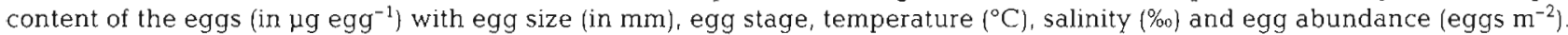

Partial correlations are shown in parentheses

\begin{tabular}{|c|c|c|c|c|c|c|c|c|c|c|}
\hline & Constant & Egg size & $\begin{array}{c}\text { Egg } \\
\text { stage }\end{array}$ & Temperature & Salinity & $\begin{array}{c}\text { Egg } \\
\text { abundance }\end{array}$ & $r^{2}$ & df & $F$ & $\mathrm{p}$ \\
\hline \multicolumn{11}{|l|}{ Scomber scombrus } \\
\hline Total protein & -23.832 & $0.999(0.32)$ & & $-9.327(-0.22)$ & $3.247(0.12)$ & & 0.17 & 3,150 & 10.0 & 0.000 \\
\hline Total carbohydrate & 4.626 & & $0.505(0.21)$ & & & & 0.04 & 1,152 & 6.7 & 0.011 \\
\hline Total lipid & 9.599 & $0.260(0.06)$ & $0.567(0.15)$ & $5.046(0.22)$ & $-2.302(0.06)$ & $0.003(0.20)$ & 0.10 & 5,200 & 4.6 & 0.001 \\
\hline \multicolumn{11}{|l|}{ Trachurus trachurus } \\
\hline Total protein & -1267.081 & & & & $36.261(0.63)$ & $0.151(0.10)$ & 0.73 & 2,23 & 31.6 & 0.000 \\
\hline Total lipid & 1.264 & & & & & $0.032(0.42)$ & 0.18 & 1,35 & 7.7 & 0.009 \\
\hline
\end{tabular}

Table 4. Sardina pilchardus, Trachurus trachurus and Engraulis encrasicolus. Means \pm SD of larval size (mm), protein, carbohydrate and lipid content (in $\mu \mathrm{g}$ larva ${ }^{-1}$ ) and larval abundance (larvae $\mathrm{m}^{-2}$ ). Number of larvae analysed at each station for protein, carbohydrate and lipid was between 3 and 16

\begin{tabular}{|c|c|c|c|c|c|}
\hline Stn & Size & Protein & Carbohydrate & Lipid & Abundance \\
\hline \multicolumn{6}{|c|}{ Sardina pilchardus } \\
\hline 2 & $9.73 \pm 2.83$ & $145.6 \pm 120.2$ & $24.3 \pm 14.8$ & $57.6 \pm 35.7$ & 124.5 \\
\hline 3 & $6.70 \pm 0.00$ & $39.2 \pm 0.0$ & $8.6 \pm 0.0$ & $14.6 \pm 0.0$ & 6.5 \\
\hline 9 & $12.36 \pm 2.70$ & $216.8 \pm 119.2$ & $25.0 \pm 8.9$ & $138.5 \pm 52.0$ & 31.7 \\
\hline 10 & $5.43 \pm 2.45$ & $37.5 \pm 40.1$ & $7.6 \pm 8.2$ & $66.6 \pm 67.5$ & 416.9 \\
\hline 11 & $9.67 \pm 4.52$ & $144.7 \pm 142.1$ & $26.2 \pm 10.1$ & $108.4 \pm 100.8$ & 153.8 \\
\hline 12 & $7.72 \pm 2.54$ & $105.2 \pm 140.7$ & $12.3 \pm 5.6$ & $95.3 \pm 39.8$ & 118.5 \\
\hline 20 & $8.17 \pm 5.70$ & $222.6 \pm 264.2$ & $7.1 \pm 0.6$ & $104.9 \pm 69.6$ & 91.6 \\
\hline 21 & $7.00 \pm 1.81$ & $19.2 \pm 13.6$ & $12.0 \pm 6.4$ & $137.6 \pm 49.0$ & 70.8 \\
\hline 30 & $7.79 \pm 2.22$ & $113.4 \pm 140.4$ & $20.1 \pm 8.9$ & $83.5 \pm 47.7$ & 238.7 \\
\hline 31 & $6.99 \pm 1.58$ & $76.9 \pm 41.8$ & $10.5 \pm 3.3$ & $102.1 \pm 27.6$ & 109.2 \\
\hline 40 & $7.95 \pm 1.78$ & $74.1 \pm 32.0$ & $16.8 \pm 8.8$ & $98.9 \pm 27.5$ & 68.1 \\
\hline \multicolumn{6}{|c|}{ Trachurus trachurus } \\
\hline 30 & $3.93 \pm 0.51$ & $52.6 \pm 25.7$ & $9.4 \pm 5.5$ & $30.4=5.8$ & 153.3 \\
\hline 31 & $2.64 \pm 0.55$ & $13.3 \pm 8.6$ & $10.4 \pm 3.0$ & $24.3 \pm 0.0$ & 77.1 \\
\hline 40 & $3.82 \pm 1.13$ & $33.2 \pm 17.5$ & $13.9 \pm 5.4$ & $44.1 \pm 23.2$ & 38.9 \\
\hline 108 & $3.96 \pm 0.64$ & $83.3 \pm 41.4$ & $12.7 \pm 5.5$ & $26.9 \pm 18.9$ & 76.6 \\
\hline 109 & $4.75 \pm 0.72$ & $62.4 \pm 27.8$ & $10.6 \pm 6.0$ & $26.1 \pm 17.0$ & 394.5 \\
\hline \multicolumn{6}{|c|}{ Engraulis encrasicolus } \\
\hline $46^{\circ}$ & $8.72 \pm 2.25$ & $172.0 \pm 139.7$ & $20.1 \pm 11.2$ & $22.2 \pm 18.4$ & 85.4 \\
\hline 55 & $5.70 \pm 2.05$ & $57.5 \pm 82.4$ & $12.3 \pm 8.9$ & $18.7 \pm 8.1$ & 95.1 \\
\hline 56 & $4.94 \pm 1.85$ & $31.9 \pm 36.1$ & $8.8 \pm 5.0$ & $25.5 \pm 15.0$ & 144.1 \\
\hline 58 & $7.03 \pm 0.52$ & $27.6 \pm 20.3$ & $19.1 \pm 11.6$ & $13.0 \pm 14.2$ & 155.9 \\
\hline 60 & $6.6 \pm 32.05$ & $49.3 \pm 38.5$ & $11.9 \pm 10.4$ & $12.1 \pm 9.7$ & 115.9 \\
\hline 61 & $9.01 \pm 2.52$ & $96.4 \pm 67.3$ & $23.6 \pm 15.9$ & $45.7 \pm 33.6$ & 254.5 \\
\hline
\end{tabular}

\section{DISCUSSION AND CONCLUSIONS}

It has been shown that either protein (Sparus aurata; Fyhn 1989, Rønnestad et al. 1994) or lipid (Sciaenops ocellata; Vetter et al. 1983) is the most important source of energy during egg development in fish. In other fish species, e.g. Atlantic halibut Hippoglossus hippoglossus, egg biochemical composition was found to be more size-dependent than egg stage-dependent (Finn et al. 1991), although in further species, e.g. Pseudopleuronectes americanus, protein and lipid concentration of the eggs were independent of egg size (Buckley et al. 1991b). In this study, however, the biochemical composition of wild eggs of Scomber scombrus and Trachurus trachurus was not highly correlated to either egg stage, egg size or egg abundance (Table 3). The lack of correlation between egg biochemical composition and egg abundance is hardly surprising because it has been shown that egg abundance in the field cannot be equated with offspring numbers collected from a single female under controlled conditions (Buckley et al. 1991a).

Egg biochemical composition of Scomber scombrus and Trachurus trachurus did not vary according to 
Table 5. Engraulis encrasicolus, Trachurus trachurus and Sardina pilchardus. Stepwise linear regressions between total protein, carbohydrate and lipid content of the larvae (in $\mu \mathrm{g}$ larva $^{-1}$ ) and percent of larval protein, carbohydrate and lipid with larval size (in $\mathrm{mm}$ ), temperature $\left({ }^{\circ} \mathrm{C}\right.$ ), salinity (\%) and larval abundance (larvae $\mathrm{m}^{-2}$ ). Partial correlations are shown in parentheses

\begin{tabular}{|c|c|c|c|c|c|c|c|c|c|}
\hline & Constant & Larval size & Temperature & Salinity & arval abundance & $r^{2}$ & $\mathrm{df}$ & $F$ & $\mathrm{p}$ \\
\hline \multicolumn{10}{|l|}{ Engraulis encrasicolus } \\
\hline Total protein & -9802.599 & $28.200(0.76)$ & $97.331(-0.15)$ & $240.009(0.36)$ & $-0.421(-0.12)$ & 0.70 & 4,47 & 27.7 & 0.000 \\
\hline Total carbohydrate & -8.145 & $3.508(0.84)$ & & & & 0.70 & 1,44 & 104.6 & 0.000 \\
\hline Total lipid & -2929.387 & $2.592(0.42)$ & $42.311(0.10)$ & $66.954(0.11)$ & $0.130(0.07)$ & 0.40 & 4,33 & 5.4 & 0.002 \\
\hline Percent protein & -15.855 & $0.043(0.58)$ & & $0.457(0.54)$ & & 0.50 & 2,33 & 16.1 & 0.000 \\
\hline Percent carbohydrate & 22.842 & & $-0.224(0.257)$ & $-0.559(-0.49)$ & & 0.36 & 2,33 & 9.2 & 0.001 \\
\hline Percent lipid & -1.573 & $-0.045(-0.62)$ & $0.163(0.401)$ & & & 0.44 & 2,33 & 13.3 & 0.000 \\
\hline \multicolumn{10}{|l|}{ Trachurus trachurus } \\
\hline Total protein & 4505.034 & $22.941(0.68)$ & & $-128.663(-0.27)$ & & 0.60 & 2,32 & 23.7 & 0.000 \\
\hline Total lipid & -23.310 & $14.570(0.51)$ & & & $-0.050(-0.15)$ & 0.41 & 2,25 & 8.6 & 0.001 \\
\hline Percent protein & 676.697 & & $-46.398(-0.54)$ & & $-0.026(0.18)$ & 0.33 & 2,23 & 5.5 & 0.011 \\
\hline Percent carbohydrate & e -17.812 & $-5.490(-0.38)$ & $14.464(0.52)$ & $45.132(0.26)$ & & 0.67 & 3,25 & 16.9 & 0.000 \\
\hline Percent lipid & -298.632 & & $24.831(0.41)$ & & & 0.17 & 1.24 & 4.9 & 0.037 \\
\hline \multicolumn{10}{|l|}{ Sardina pilchardus } \\
\hline Total protein & -3774.232 & $33.748(0.84)$ & $-24.936(-0.24)$ & $111.051(-0.06)$ & $0.128(-0.16)$ & 0.73 & 4,88 & 60.1 & 0.000 \\
\hline Total carbohydrate & -3.809 & $2.541(0.76)$ & & & & 0.58 & 1,90 & 124.8 & 0.000 \\
\hline Total lipid & -165.648 & $5.297(0.50)$ & $11.770(0.19)$ & & & 0.33 & 2,85 & 20.5 & 0.000 \\
\hline Percent protein & -7.189 & $0.029(0.47)$ & $-0.131(-0.46)$ & $0.263(-0.04)$ & & 0.41 & 3,75 & 17.4 & 0.000 \\
\hline Percent carbohydrate & 0.184 & $-0.006(-0.23)$ & & & & 0.05 & 1,77 & 4.2 & 0.043 \\
\hline Percent lipid & -1.183 & $-0.025(-0.39)$ & $0.128(0.47)$ & & & 0.37 & 3,75 & 14.8 & 0.000 \\
\hline
\end{tabular}

changes in either temperature or salinity (Table 3). Therefore, for these 2 species, changes in protein, carbohydrate and lipid content of the eggs were not observed as a mechanism to modify egg buoyancy. This result is in agreement with those that considered the function of lipid in the eggs as nutritive and not as hydrostatic (Craik \& Harvey 1987). As vertical distribution of pelagic eggs is more influenced by wind-induced mixing than by egg buoyancy (Coombs et al. 1985 , Sundby 1991), to assure optimal buoyancy, it is probably enough to produce eggs of a density which allows the eggs to stay buoyant in the upper layers according to the prevailing range of salinity in the spawning areas, additional strategies such as changes in the biochemical composition of the eggs not being necessary.

The variation in the egg biochemical composition observed for these 2 species could be due to the influence of other factors, such as parental effect. Other studies have shown that female size and spawning time affect egg size, fecundity and egg viability (Buckley et al. 1991b, Kjesbu et al. 1992).

Conversely, larval size, temperature and salinity were found to be important factors which affected the biochemical composition of larvae in Sardina pilchardus, Trachurus trachurus and Engraulis encrasicolus (Table 5). The trade-off observed between protein and lipid as temperature changed (Fig. 2) could be explained as a response in order to achieve optimal larval buoyancy. From total organic investment either a higher proportion of protein or lipid is synthesised according to prevailing buoyancy conditions.
The differences found between egg and larval stages in protein, carbohydrate and lipid contents, as water density changed, could be explained according to some of these assumptions: in the egg stage it is not possible to modify the biochemical composition; to achieve optimal buoyancy in the larval stage is of higher value in the recruitment process than in the egg stage; and finally, as has been mentioned above, vertical distribution of pelagic eggs is mainly influenced by wind-induced mixing, possible changes in egg buoyancy due to possible variations in egg biochemical composition being of minor importance.

Larval abundance could affect the biochemical composition of larvae due to a possible food depletion at high larval densities. Although some of the larval densities found in this study for the 3 species were similar to the maximum values observed in this area (Dicenta 1984), larval abundance was not as important a factor as larval size and temperature and, moreover, the significant relationships observed showed no clear pattern of the possible influence of intraspecific competition on larval protein, carbohydrate and lipid contents in Sardina pilchardus, Trachurus trachurus and Engraulis encrasicolus (Table 5).

Larval carbohydrate content was not affected by changes in water temperature and salinity. This component was found to be size-dependent in the larval stage. The proportion of carbohydrate was very low in both eggs (Table 2) and larvae (Table 4) when compared with the amounts of protein and lipid. It seems this component is not an important source of energy 

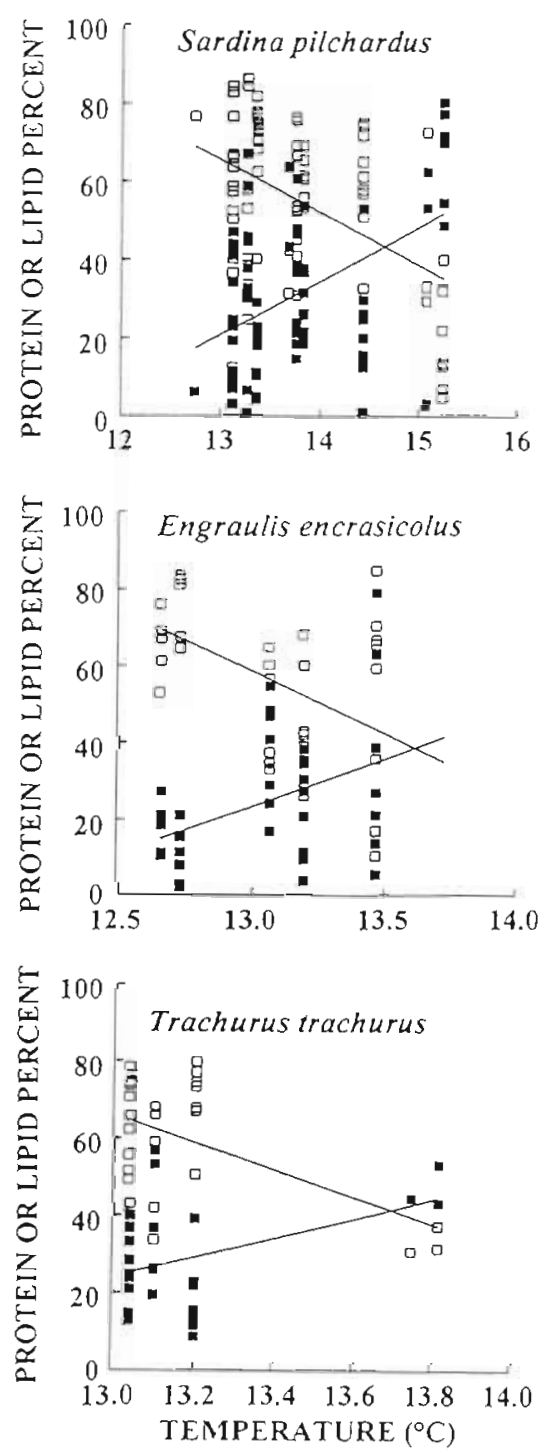

Fig. 2. Relationships between percentage of protein $(\boldsymbol{\square})$ and lipid ( $\square$ ) and mean temperature of the whole water column for Sardina pilchardus (for protein $\mathrm{r}^{2}=0.21, F_{1.77}=20.3, \mathrm{p}<0.001$ and for lipid $r^{2}=0.22, F_{1,77}=22.1, p<0.001$ ), Trachurus trachurus (for protein $\mathrm{r}^{2}=0.28, F_{1,24}=9.6, \mathrm{p}=0.005$ and for lipid $\mathrm{r}^{2}=0.17, F_{1.24}=4.8, \mathrm{p}=0.037$ ) and Engraulis encrasicolus (for protein $r^{2}=0.22, F_{1,34}=9.9, p=0.003$ and for lipid $r^{2}=0.16$, $F_{1,34}=6.5, \mathrm{p}=0.015$ )

during embryonic and larval development, the main proportion of total carbohydrate probably being structural (Heming \& Buddington 1988).

In summary, the variation found in egg protein, carbohydrate and lipid content of Scomber scombrus and Trachurus trachurus was not related with changes in either egg size, egg stage or egg abundance, nor was it a mechanism to modify egg buoyancy. However, a high proportion of the variation found in larval biochemical composition was explained by changes in lar-

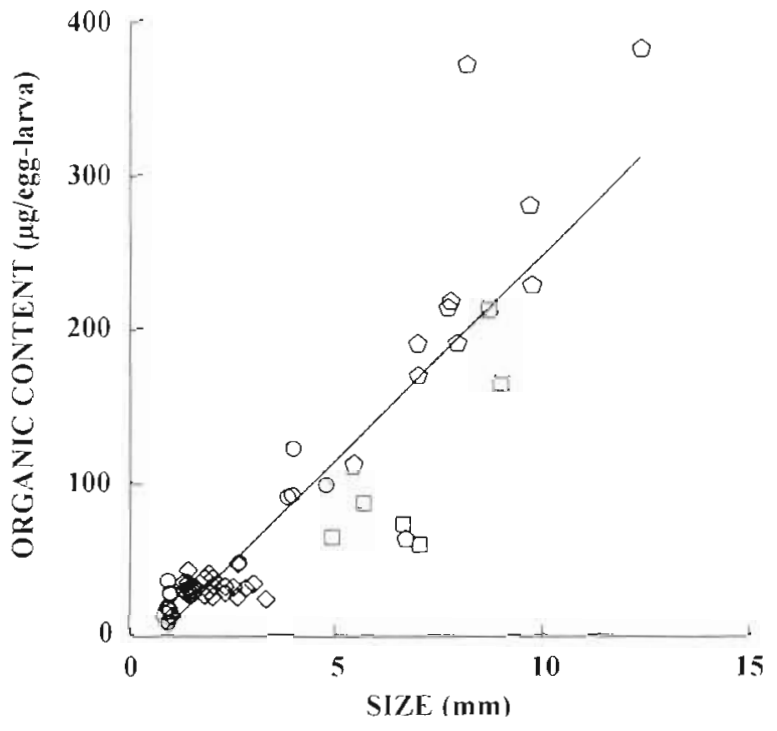

Fig. 3. Relationship between egg and larval organic content $1 O$, combined total protein, carbohydrate and lipid content in $\mu \mathrm{g})$ and size $(S, \mathrm{in} \mathrm{mm}$ ) for Sardina pilchardus ( 0 ), Trachurus trachurus $(O)$, Scomber scombrus $(\diamond)$ and Engraulis encrasicolus $(\square) . O=-18.827+26.673 S, \mathrm{r}^{2}=0.8, F_{1.55}=219.7$.

$$
p<0.001
$$

val size, temperature and/or salinity. An increment in larval organic content of Sardina pilchardus, T. trachurus and Engraulis encrasicolus was observed as larval size increased. However, a higher proportion of either protein or lipid was synthesised according to water density, probably as a strategy directed toward achieving optimal larval buoyancy.

Acknowledgements. We thank J. M. Cabanas for supplying temperature and salinity data for the field stations, M. Varela and I. Soler for useful help in the laboratory, the ichthyoplankton group of I.E.O. of Madrid for supplying egg and larval abundance data and for their help during both cruises, and 3 anonymous referees for their useful comments.

\section{LITERATURE CITED}

Anderson JT, DeYoung B (1995) Application of a one-dimensional model to vertical distributions of cod eggs on the northeastern Newfoundland Shelf. Can J Fish Aquat Sci $52: 1978-1989$

Anonymous (1994) Report of the Mackerel/Horse mackerel egg production workshop. ICES CM 1994/H:4

Buckley LJ, Smigielski AS, Halavik TA, Caldarone EM, Burns BR, Laurence GC (1991a) Winter flounder Pseudopleuronectes americanus reproductive success. I. Among-location variability in size and survival of larvae reared in the laboratory. Mar Ecol Prog Ser 74:117-124

Buckley LJ, Smigielski AS, Halavik TA, Caldarone EM, Burns BR, Laurence GC (1991b) Winter flounder Pseudopleuronectes americanus reproductive success. II. Effects of spawning time and female size on size, composition 
and viability of eggs and larvae. Mar Ecol Prog Ser 74: $125-135$

Coombs SH, Fosh CA, Keen MA (1985) The buoyancy and vertical distribution of eggs of sprat (Sprattus sprattus) and pilchard (Sardina pilchardus). J Mar Biol Assoc UK 65: $461-474$

Craik JCA, Harvey SM (1987) The causes of buoyancy in eggs of marine teleosts. J Mar Biol Assoc UK 67:169-182

Dicenta A (1984) Aportación al conocimiento del ictioplancton de la costa vasca. Bol Inst Esp Oceanogr 1:94-105

Dubois M, Gilles KA, Hamilton JK, Smith F (1956) Colorimetric method for determination of sugars and related substances. Anal Chem 28:350-356

Finn RN, Fyhn HJ, Evjen MS (1991) Respiration and nitrogen metabolism of Atlantic halibut eggs (Hippoglossus hippoglossus). Mar Biol 108:11-19

Fyhn HJ (1989) First feeding of marine fish larvae: are free amino acids the source of energy? Aquaculture 80 $111-120$

Fyhn HJ, Serigstad B (1987) Free amino acids as energy substrate in developing eggs and larvae of cod Gadus morhua. Mar Biol 96:335-341

Heming TA, Buddington RK (1988) Yolk absorption in embryonic and larval fishes. In: Hoar WS, Randall DJ (eds) Fish physiology, Vol 11A. Academic Press Inc, Boston, p 407-446

Kjesbu OS, Kryvi H, Sundby S, Solemdal P (1992) Buoyancy variations in eggs of Atlantic cod (Gadus morhua L.) in relation to chorion thickness and egg size: theory and observations. J Fish Biol 41:581-599

Lee MA, Lee KT, Shiah GY (1995) Environmental factors associated with the formation of larval anchovy fishing grounds in the coastal waters of southwest Taiwan. Mar Biol 121:621-625

Lockwood SJ, Nichols JH (1977) The development rates of mackerel (Scomber scombrus L.) eggs over a range of temperature. ICES CM/J:13

Lowry OH, Rosenbraugh NJ, Farr AL, Randall RJ (1951) Protein measurements with the Folin phenol reagent. J Biol Chem 193:256-275

Markwell MAK, Haas SM, Bieber LL, Tolbert NE (1978) A modification of the Lowry procedure to simplify protein

Editorial responsibility: Otto Kinne (Editor),

Oldendorf/Luhe, Germany determination in membrane and lipoprotein samples. Anal Biochem 87:206-210

Miranda A, Cal RM, Iglesias J (1990) Effect of temperature on the development of eggs and larvae of sardine Sardina pilchardus Walbaum in captivity. J Exp Mar Biol Ecol 140: $69-77$

Nissling A, Westin L (1991) Egg buoyancy of Baltic cod (Gadus morhua) and its implications for cod stock fluctuations in the Baltic. Mar Biol 111:33-35

Page F, Frank KT, Thompson KR (1989) Stage dependent vertical distribution of haddock (Melanogrammus aeglefinus) eggs in a stratified water column: observations and model. Can J Fish Aquat Sci 46:55-67

Pipe RK, Walker P (1987) The effect of temperature on development and hatching of scad Trachurus trachurus L., eggs. J Fish Biol 31:675-682

Rønnestad I, Koven WM, Tandler A, Harel M, Fyhn HJ (1994) Energy metabolism during development of eggs and larvae of gilthead sea bream (Sparus aurata). Mar Biol 120: $187-196$

Solá A, Motos L, Franco C, Lago de Lazós A. (1990) Seasonal occurrence of pelagic fish eggs and larvae in the Cantabrian Sea (IIXC) and Galician (IXa) from 1987 to 1989. ICES CM 1990/H:26

Srivastava RK, Brown JA (1991) The biochemical characteristics and hatching performance of cultured and wild Atlantic salmon (Salmo salar) eggs. Can J Zool 69:2436-2441

Sundby $S$ (1991) Factors affecting the vertical distribution of eggs. ICES Mar Sci Symp 192:33-38

Tamaru CS, Ako H, Lee CS (1992) Fatty acid and amino acid profiles of spawned eggs of striped mullet, Mugil cephalus L. Aquaculture 105:83-94

Vetter RD, Hodson RE, Arnold C (1983) Energy metabolism in a rapidly developing marine fish egg, the red drum ( $\mathrm{SCi}$ aenops ocellata). Can J Fish Aquat Sci 40:627-634

Watanabe $T$ (1982) Lipid nutrition in fish. Comp Biochem Physiol 73(B):3-15

Zöllner N, Kirsch K (1962) Über die quantitative Bestimmung von Lipoiden (Mikromethode) mittels der vielen natürlichen Lipoiden (allen bekannten Plasmalipoiden) gemeinsamen Sulfophosphovanillin-Reaktion. Z Ges Exp Med 135:545-561

Submitted: July 21, 1997; Accepted: January 2, 1998

Proofs received from author(s): February 19, 1998 